\title{
PERCEPCIJA KVALITETA ODNOSA UNUTAR PORODICE - ISKUSTVO ADOLESCENATA IZ SRBIJE'
}

\section{Ivana Mihić ${ }^{2}$ Jelica Petrović}

Odsek za psihologiju, Filozofski fakultet, Univerzitet u Novom Sadu

Istraživanje prikazano ovim radom opisuje specifičnosti porodice u Srbiji kao razvojnog okruženja u adolescenciji. Uzorak istraživanja činilo je 780 ispitanika, prosečnog uzrasta 19 godina. Uzorkom su obuhvaćeni mladi u srednjoj $i$ kasnoj adolescenciji (raspon godina bio je od 15-28). $U$ istraživanju je korišten srpski prevod Inventara mreže socijalnih odnosa (Network of Relationships Inventory -NRI, Furman, Buhrmaster, 1985), sa 9 merenih dimenzija odnosa: Prijateljstvo (Companionship), Instrumentalna pomoć (Instrumental Aid), Intimnost (Intimacy), Sigurnost u trajnost odnosa (Reliable Alliance), Poštovanje (Admiration), Briga (Nurturance) i Privrženost (Affection) (kao mere pozitivne razmene), te Konflikti (Conflict) i Antagonizam (Antagonism) (kao mere negativne interakcije).

Rezultati ukazuju na značajne razlike u percepciji odnosa sa majkom $i$ ocem, koje jasno oslikavaju društveno normirane uloge roditelja. Odnos sa siblingom je značajno različit od odnosa sa roditeljima $i$ uključuje više simetričnosti.

Rezultati su prodiskutovati u kontekstu doprinosa dominirajućih kulturnih vrednosti proceni odnosa unutar porodice.

Ključne reči: adolescencija, odnosi u porodici

\footnotetext{
${ }^{1}$ Istraživanje je u okviru projekta broj 149008 «Psihološke karakteristike društva u tranziciji» koji podržava Ministarstvo nauke i tehnološkog razvoja Republike Srbije.

${ }^{2}$ Adresa autora: imihic@ff.uns.ac.rs
} 
Razvoj podrazumeva stupanje u veliki broj različitih interpersonalnih relacija, čime se mreža ljudi sa kojima se ostvaruju bliski i uticajni odnosi širi od primarnih porodičnih relacija ka velikom broju drugih, specifičnih odnosa sa osobama i institucijama van porodičnog sistema. Iako su u istraživačkom fokusu najčešće efekti ili kvalitet pojedinačnih dijadnih relacija, sistemska porodična teorija značajno je doprinela pomeranju fokusa istraživanja ka dobijanju celovitijih slika o kontekstu razvoja pojedinca, što onda podrazumeva podatke o mreži različitih relacija i njihovoj međuzavisnosti (Collins i Laursen, 2004; Collins i sar, 2007). Već osamdesetih, istraživanja u značajnoj meri odgovaraju ovakvom uticaju (Bryant, 1985, Furman, Buhrmester, 1985; 1987; 1990). Od tada, istraživanja koja su se bavila mrežama relacija razvijala su se u dva smera: ka strukturalnom pristupu (koji je uzimao u obzir karakteristike kao što je broj ljudi u mreži, prisustvo ili odsustvo pojedinih članova porodice i slično) (Urberg i sar, 1995), i ka funkcionalnom pristupu (koji uzima u obzir kvalitativne aspekte relacija (Buhrmaster, 1990; Furman, Buhrmaster, 1990; 1992; Gavin, Furman, 1996; Collins Laursen, 2004; Wissink i sar, 2006; Buhl, 2008). Osnovni nedostatak ovih studija predstavlja, pre svega, nedostatak jedinstvenog okvira za razumevanje razvoja interpersonalnih relacija (Van Horn, Marques, 2000) iako su podaci koji se dobijaju studijama sa funkcionalnim pristupom uglavnom konzistentni sa teorijama psihosocijalnog razvoja. Kroskulturalna istraživanja ukazuju na značaj ekoloških modela, koji podrazumevaju jasne uticaje iz makrosistema koji su vidljivi u istraživanjima (Georgas i sar, 2001), ali se nameću i u praktičnom i terapijskom radu sa pojedincima i porodicama (Mc Goldric, 1998; Mc Goldric, Giordano, 1996.). Ovako predstavljeni efekti dominirajućih vrednosti, ali i stavova relevantnih socijalnih institucija, zakona i normi, zapravo su način da se obuhvate i razumeju efekti dominirajuće društvene klime na specifičnosti porodičnih i drugih relacija značajnih za razvoj pojedinca.

Specifičnosti srpskog društva pre svega se odnose na dominirajući koncept tradicionalnih uloga vezanih za pol i porodične uloge, zatim kolektivizma kao vrednosti koja visoko ističe značaj porodice i porodičnih interesa, naspram individualističkih interesa i razvoja pojedinca. U tom smislu, ova kultura značajno je različita od evropskih individualistički orijentisanih društava. Proces egalitarizacije uloga imao je značajan upliv u dominantne vrednosti nakon drugog svetskog rata i njegov efekat bio je vidljiv pre svega u povećanju broja žena koje rade i školuju se (Somerwill, 1965). Istorijski kontekst koji je usledio, i koji je, pre svega okarakterisan kontinuiranim izraženim stresom vezanim za materijalno stanje, ali i fizičku sigurnost (u smislu ratova i izbeglištva), imao je za posledicu vraćanje ranijim obrascima funkcionisanja porodice koju pojedini autori karakterišu kao retradicionalizacija (Tomanović, 2004). U Srbiji tako, 
prema istraživanjima oko $77 \%$ porodica funkcioniše po tradicionalnom sistemu, bar kad je u pitanju jasna dihotomna podela uloga: majci se dodeljuje primat u brizi o kući i ukućanima, dok je otac primarno orijentisan na sticanje, materijalnu sigurnost porodice i fizički rad u kući ( Mihić i sar, 2006; Petrović, 2007; Zotović i sar, 2007). Aktuelni porodični problemi vezuju se pre svega za zahteve za uspostavljanjem egalitarnijih odnosa kojima se preporučuje veća uključenost oca u život i odnose u porodici, a veća individuacija majki. Pri tom, stanje koje je okarakterisano kao „vrednosni vakuum“ implicira gubljenje tradicionalnih vrednosti bez uspostavljenih novih vrednosti. Tako se u društvu danas govori o različitoj problematici kojom se opisuju promene u porodici čiji se karakter „klima“ između napretka i „propasti“" porodice kao vrednosti.

Istraživanje predstavljeno ovim radom ima za cilj da opiše specifičnosti porodice u Srbiji kao razvojnog okruženja u adolescenciji, kao i da ispita doprinose dominirajućih kulturnih vrednosti proceni odnosa unutar porodice.

\section{Metod}

\section{Uzorak}

Uzorak istraživanja činilo je 780 ispitanika, prosečnog uzrasta 19 godina. Uzorkom su obuhvaćeni mladi u srednjoj i kasnoj adolescenciji (raspon godina bio je od 15-28). Ispitanici su učenici gimnazija i srednjih stručnih škola i studenti dva univerzitetska grada sa teritorije Srbije. Kako je većina ispitanika iz gradova i univerzitetskih centara, uzorak oslikava uglavnom mlade iz urbanih mesta, porodica srednje klase.

83,5\% ispitanika iz uzorka dolazi iz potpunih porodica, dok $15,9 \%$ živi u porodicama nastalim nakon razvoda ili smrti jednog od roditelja (jednoroditeljske porodice $12,6 \%$ ili step parent families, 2,3\%). Ovako sačinjen uzorak odgovara većini populacionih studija u Srbiiji. 72,9\% ispitanika ima braće ili sestara. 52,9\% ispitanika je prvorođeno dete, $40,9 \%$ drugo ili poslednje rođeno, a $6,2 \%$ je srednje od troje dece.

U uzorku je oko $32 \%$ mladića i $68 \%$ devojaka.

Istraživanje je obavljano u školama i fakultetima, grupno. Nastavnik je bio prisutan i dao saglasnost za sprovođenje ispitivanja. Za ispitanike srednjoškolskog uzrasta, saglasnost je dobijena i od učesnika i direktora škola. 


\section{Instrument}

U istraživanju je korišten srpski prevod Inventara mreže socijalnih odnosa (Network of Relationships Inventory -NRI, Furman, Buhrmaster, 1985). NRI je preveo drugi autor ovog rada. Prvi prevod je proveren na pilot uzorku od 120 ispitanika (studenata Univerziteta u Novom Sadu) kako bi se proverila valjanost prevoda..

Primenjena verzija Inventara mreže socijalnih odnosa ima 27 stavki kojima je moguće proceniti 9 dimenzija odnosa (primeri ajtema dati su u zagradama): Prijateljstvo (Companionship- "svoje slobodno vreme provodim sa njom"); Instrumentalna pomoć (Instrumental aid- "pomaže mi da rešim određene probleme"); Intimnost (Intimacy- "sve svoje tajne delim sa njom"); Briga (Nurturance- "vodim računa o njoj"); Privrženost (Affection- "siguran sam da joj je stalo do mene"); Poštovanje (Admiration-"siguran sam da me poštuje"); Sigurnost u trajnost odnosa (Reliable alliance- "siguran sam da će naš odnos opstati bez obzira na sve") kao mere pozitivne razmene i Konflikt (Conflict"često se posvađamo"); Antagonizam (Antagonism- "često prigovaramo jedno drugom") kao mere negativne interakcije. Autori skale su kao konceptualni okvir koristili Vajsovu teoriju socijalne podrške (Weiss, 1974; prema Furman, Buhrmaster, 1985) po kojoj pojedinačni članovi mreže socijalnih odnosa (otac, majka, sibling, prijatelj, partner...) obezbeđuju različite oblike socijalne podrške, te da je svaka od njih od različitog značaja na različitim uzrastima.

Unutrašnja konzistentnost za celu skalu, merena Kronbahovim alfa koeficijentom je veoma visoka i iznosi 0,94 . Kronbahovi alfa koeficijenti računati su posebno za svaku relaciju i svaku podskalu i sve mere su se pokazale veoma prihvatljivim za sve procenjivane odnose (od 0,81-0,92 za odnos sa ocem, od 0,62-0,90 za odnos sa majkom i od 0,79-0,93 za odnos u sibling relaciji).

\section{Rezultati}

\section{Deskriptivni pokazatelji}

Rezultati na celokupnom uzorku ukazuju na pravilnost da se dosledno najniži skorovi na svim merenim dimenzijama Inventara mreže socijalnih odnosa pripisuju odnosu sa ocem. Naročito su niski skorovi vezani za intimnost, ali i skorovi na subskalama koje mere prijateljstvo i subskalama koje opisuju konfliktne odnose (Konflikti i Antagonizam). Za razliku od procenjenog odnosa sa ocem, adolescenti iz uzorka procenjuju dosledno kvalitetnijim odnos sa majkom. Najviši skorovi kada je u pitanju odnos sa majkom vezuju 
se za subskale koje mere instrumentalnu pomoć, ali i druge elemente pozitivne emotivne i socijalne razmene (Privrženost, Poštovanje, Sigurnost u trajnost odnosa ). Kada je u pitanju percepcija kvaliteta odnosa u relaciji sa siblingom, najviši skorovi vezuju se za dimenzije koje mere negativnu interakciju (konflikti i antagonizam). U isto vreme, u odnosu sa siblingom visoki su skorovi i na Prijateljstvu, Intimnosti, Brizi i Privrženosti, što su mere pozitivne razmene. Svi deskriptivni pokazatelji prikazani su na grafiku 1.

Grafik 1. Deskriptivni pokazatelji kvaliteta relacija- celokupan uzorak

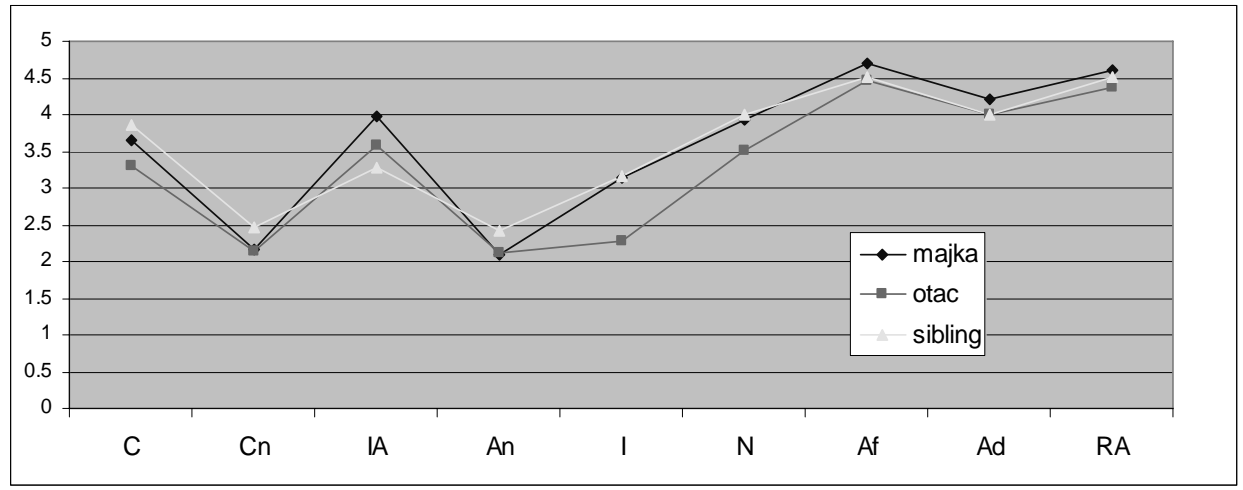

Legenda:

C-Prijateljstvo (Companionship)

Cn-Konflikt (Conflict)

IA- Instrumentalna pomoć (Instrumental Aid)

An-Antagonizam (Antagonism)

I- Intimnost (Intimacy)

$\mathrm{N}$ - Briga (Nurturance)

Af- Privrženost (Affection)

Ad-Poštovanje (Admiration)

RA-Sigurnost u trajnost odnosa (Reliable Alliance)

Razlike u percepciji kvaliteta odnosa u tri merene relacije su se pokazale statistički značajnim na svim dimenzijama (tabela 1). 
Tabela 1. Razlike u percepciji kvaliteta relacija sa ocem, majkom i siblingom

\begin{tabular}{|c|c|c|c|c|c|}
\hline Subskala & & $\begin{array}{l}\text { Prosečna } \\
\text { vrednost }\end{array}$ & $\mathrm{Sd}$ & $\mathrm{F}$ & $p$ \\
\hline \multirow{3}{*}{ Prijateljstvo (C) } & Odnos sa majkom & 3.63 & .97 & \multirow{3}{*}{89.897} & \multirow{3}{*}{$<.01$} \\
\hline & Odnos sa ocem & 3.29 & 1.05 & & \\
\hline & Odnos sa siblingom & 3.86 & 1.05 & & \\
\hline \multirow{3}{*}{ Konflikt (Cn) } & Odnos sa majkom & 2.17 & .82 & \multirow{3}{*}{42.686} & \multirow{3}{*}{$<.01$} \\
\hline & Odnos sa ocem & 2.14 & .86 & & \\
\hline & Odnos sa siblingom & 2.48 & 1.00 & & \\
\hline \multirow{3}{*}{$\begin{array}{l}\text { Instrumentalna } \\
\text { pomoć (IA) }\end{array}$} & Odnos sa majkom & 3.97 & 1.19 & \multirow{3}{*}{94.938} & \multirow{3}{*}{$<.01$} \\
\hline & Odnos sa ocem & 3.57 & 1.14 & & \\
\hline & Odnos sa siblingom & 3.27 & 1.16 & & \\
\hline \multirow{3}{*}{ Antagonizam (An) } & Odnos sa majkom & 2.09 & .87 & \multirow{3}{*}{41.102} & \multirow{3}{*}{$<.01$} \\
\hline & Odnos sa ocem & 2.10 & .92 & & \\
\hline & Odnos sa siblingom & 2.41 & 1.01 & & \\
\hline \multirow{3}{*}{ Intimnost (I) } & Odnos sa majkom & 3.14 & 1.32 & \multirow{3}{*}{160.614} & \multirow{3}{*}{$<.01$} \\
\hline & Odnos sa ocem & 2.28 & 1.08 & & \\
\hline & Odnos sa siblingom & 3.16 & 1.34 & & \\
\hline \multirow{3}{*}{ Briga (N) } & Odnos sa majkom & 3.95 & 1.06 & \multirow{3}{*}{78.393} & \multirow{3}{*}{$<.01$} \\
\hline & Odnos sa ocem & 3.51 & 1.18 & & \\
\hline & Odnos sa siblingom & 3.97 & 1.15 & & \\
\hline \multirow{3}{*}{ Privrženost (Af) } & Odnos sa majkom & 4.69 & .76 & \multirow{3}{*}{14.863} & \multirow{3}{*}{$<.01$} \\
\hline & Odnos sa ocem & 4.48 & .99 & & \\
\hline & Odnos sa siblingom & 4.51 & 1.02 & & \\
\hline \multirow{3}{*}{ Poštovanje (Ad) } & Odnos sa majkom & 4.21 & .85 & \multirow{3}{*}{18.163} & \multirow{3}{*}{$<.01$} \\
\hline & Odnos sa ocem & 4.01 & .98 & & \\
\hline & Odnos sa siblingom & 3.99 & 1.07 & & \\
\hline \multirow{3}{*}{$\begin{array}{l}\text { Sigurnost u } \\
\text { trajnost odnosa } \\
\text { (RA) }\end{array}$} & Odnos sa majkom & 4.60 & .85 & \multirow{3}{*}{15.967} & \multirow{3}{*}{$<.01$} \\
\hline & Odnos sa ocem & 4.37 & 1.09 & & \\
\hline & Odnos & 4.52 & 1.0 & & \\
\hline
\end{tabular}

Post hoc analizom (LSD) uočene su razlike koje govore u prilog izraženijoj pozitivnoj razmeni u odnosu sa majkom, te izraženijoj negativnoj razmeni sa siblingom u odnosu na druge dve procenjivane relacije u porodici. Rezultati će u daljem tekstu biti prikazani po merenim dimenzijama relacija. 
Prijateljstvo (C). Ovaj aspekt odnosa najizraženiji je u relaciji sa siblingom. Razlika je statistički značajna u odnosu na relacije sa oba roditelja. Pri tom je procenjeni intenzitet ove dimenzije odnosa statistički značajno najniži $u$ relaciji sa ocem.

Konflikt (Cn). Razlika je statistički značajna između percepcije odnosa sa majkom i ocem u odnosu na percepciju odnosa sa siblingom. Pri tom, su konflikti procenjeni kao najizraženiji u sibling relaciji.

Instrumentalna pomoć (IA). Razlike su statistički značajne između svih procenjivanih odnosa. Pri tom je odnos sa majkom najobeleženiji ovom dimenzijom, a odnos sa siblingom značajno manje u odnosu na relacije sa oba roditelja.

Antagonizam (A). Kao i kod dimenzije konflikti, razlika je značajna u korist sibling relacije koja je značajno izraženije obeležena ovim aspektima interakcije.

Intimnost (I). Ovaj aspekt relacija značajno je niže zastupljen u odnosu sa ocem, nego u obe druge merene relacije. Razlika u percipiranoj intimnosti $u$ relaciji sa majkom i unutar sibling subsistema, nije statistički značajna.

Briga (N). Kao i u prethodnoj analizi, i ovaj aspekt pozitivne razmene, značajno je manje zastupljen $u$ relaciji sa ocem $u$ odnosu na obe druge procenjivane relacije (među kojima razlika nije statistički značajna).

Privrženost (Af). Ovaj aspekt odnosa, značajno je najizraženiji u relaciji sa majkom $u$ odnosu na obe druge procenjivane relacije (među kojima razlika nije statistički značajna).

Poštovanje (Ad). I ovaj aspekt pozitivne interakcije najizraženiji je u relaciji sa majkom. Razlika je statistički značajna u odnosu na obe druge procenjivane relacije. Između admirationa u odnosu sa ocem i siblingom nema značajne razlike.

Sigurnost $u$ trajnost odnosa (RA). Izraženost ovog aspekta pozitivne interakcije značajno je niža $u$ relaciji sa ocem $u$ odnosu na obe druge merene relacije. Pri tom, iako i u ovoj dimenziji kvaliteta odnosa, prednjači relacija sa majkom, razlika između percepcije ovog odnosa i odnosa u sibling relaciji nije statistički značajna.

$\mathrm{Na}$ celokupnom uzorku, uočene su i statistički značajne razlike u proceni kvaliteta procenjivanih relacija s obzirom na pol ispitanika (tabela 2). 
Tabela 2. Značajnost razlika u percipiranom kvalitetu odnosa unutar porodice s obzirom na pol ispitanika

\begin{tabular}{|c|c|c|c|c|c|}
\hline Subskala & & $\begin{array}{l}\text { Prosečna } \\
\text { vrednost }\end{array}$ & Sd & $\mathrm{t}$ & $p$ \\
\hline \multirow{2}{*}{$\begin{array}{l}\text { Prijateljstvo } \\
\text { (C)-majka }\end{array}$} & mladići & 3.50 & .95 & \multirow{2}{*}{-2.68} & \multirow{2}{*}{$<.01$} \\
\hline & devojke & 3.71 & .99 & & \\
\hline \multirow{2}{*}{ Konflikt (Cn)-majka } & mladići & 2.09 & .84 & \multirow{2}{*}{-1.71} & \multirow{2}{*}{$<.10$} \\
\hline & devojke & 2.21 & .80 & & \\
\hline \multirow{2}{*}{$\begin{array}{l}\text { Instrumentalna pomoć } \\
\text { (IA) -majka }\end{array}$} & mladići & 3.86 & .99 & \multirow{2}{*}{-1.91} & \multirow{2}{*}{$<.10$} \\
\hline & devojke & 4.03 & 1.24 & & \\
\hline \multirow{2}{*}{$\begin{array}{l}\text { Antagonizam (An) - } \\
\text { majka }\end{array}$} & mladići & 2.03 & .31 & \multirow{2}{*}{-1.41} & \multirow{2}{*}{ n.s } \\
\hline & devojke & 2.13 & .85 & & \\
\hline \multirow[t]{2}{*}{ Intimnost (I) -majka } & mladići & 2.95 & 1.18 & \multirow{2}{*}{-2.81} & \multirow{2}{*}{$<.01$} \\
\hline & devojke & 3.24 & 1.37 & & \\
\hline \multirow[t]{2}{*}{ Briga $(\mathrm{N})$-majka } & mladići & 3.88 & 1.04 & \multirow{2}{*}{-1.02} & \multirow{2}{*}{ n.s } \\
\hline & devojke & 3.97 & 1.08 & & \\
\hline \multirow{2}{*}{$\begin{array}{l}\text { Privrženost (Af) - } \\
\text { majka }\end{array}$} & mladići & 4.64 & .74 & \multirow{2}{*}{-1.33} & \multirow{2}{*}{ n.s } \\
\hline & devojke & 4.72 & .75 & & \\
\hline \multirow{2}{*}{ Poštovanje (Ad) -majka } & mladići & 4.18 & .80 & \multirow{2}{*}{-.49} & \multirow{2}{*}{ n.s } \\
\hline & devojke & 4.21 & .87 & & \\
\hline \multirow{2}{*}{$\begin{array}{l}\text { Sigurnost u trajnost } \\
\text { odnosa (RA) -majka }\end{array}$} & mladići & 4.57 & .83 & \multirow[b]{2}{*}{-.79} & \multirow{2}{*}{ n.s } \\
\hline & devojke & 4.62 & .85 & & \\
\hline \multirow[t]{2}{*}{ Prijateljstvo (C)- otac } & mladići & 3.35 & 1.01 & \multirow{2}{*}{.63} & $n c$ \\
\hline & devojke & 3.30 & 1.06 & & 11.3 \\
\hline Konflikt (Cn)-otac & mladići & 2.10 & .88 & Q & $n$ \\
\hline & devojke & 2.16 & .85 & -.98 & n.s \\
\hline Instrumentalna pomoć & mladići & 3.75 & 1.10 & 261 & 01 \\
\hline (IA))-otac & devojke & 3.51 & 1.14 & 2.01 & $<.01$ \\
\hline Antagonizam (An) - & mladići & 2.03 & .93 & 1116 & $n$ \\
\hline otac & devojke & 2.14 & .91 & -1.40 & 7.5 \\
\hline Intimnost (I) )-otac & mladići & 2.59 & 1.14 & 520 & -01 \\
\hline & devojke & 2.14 & 1.03 & $3 . \angle 0$ & $<.01$ \\
\hline Briga (N) )-otac & mladići & 3.60 & 1.15 & 147 & $n s$ \\
\hline & devojke & 3.46 & 1.19 & 1.47 & 11.5 \\
\hline Privrženost (Af) )-otac & mladići & 4.46 & .95 & -26 & $n s$ \\
\hline & devojke & 4.48 & 1.03 & -.20 & 11.5 \\
\hline Poštovanje (Ad) )-otac & mladići & 4.03 & .99 & 61 & $n s$ \\
\hline & devojke & 3.99 & .98 & .01 & 7.5 \\
\hline
\end{tabular}


Sigurnost u trajnost

odnosa (RA) )-otac

\begin{tabular}{lllll}
\cline { 1 - 1 } mladići & 4.43 & 1.00 & .81 & n.s \\
\hline devojke & 4.36 & 1.12 & & \\
\hline
\end{tabular}

Ispitanice procenjuju višim Prijateljstvo i Intimnost u odnosu sa majkom, dok ispitanici procenjuju značajno višim Intimnost i Instrumentalnu pomoć u odnosu sa ocem. Na granici statističke značajnosti su i razlike u percipiranoj izraženost konflikata i instrumentalne pomoći u odnosu sa majkom, gde ispitanice pokazuju tendenciju ka višim skorovima. U odnosu sa siblingom, uočene razlike nisu statistički značajne ni na jednoj merenoj dimenziji.

\section{Diksusija}

Istraživanje prikazano ovim radom ima za cilj da doprinese razumevanju kroskulturalnih sličnosti i razlika u percepciji kvaliteta mreže relacija unutar porodice opisujući specifičnosti procene odnosa u porodici u srpskoj kulturi.. Ekološka teorija razvoja (Bronfenbrener, 1988) ukazuje da pravilnost da je percepcija porodičnih relacija pod značajnim uplivom socijalnih normi i očekivanja vezanih za uloge i društvenu koncepciju porodice kao sistema. Kroskulturalna istraživanja do sad (Cicirelli, 1994; Georgas i sar, 2001) pokazala su da se procene odnosa zaista značajno razlikuju. Pretpostavka sa kojom se ušlo u ovo istraživanje je bila da će percepcija odnosa unutar porodice značajno reflektovati karakteristike aktuelnih vrednosti i normi vezanih za porodične uloge i relacije u Srbiji.

Rezultati na celokupnom uzorku ukazuju na značajne razlike u opažanju kvaliteta odnosa u porodičnim subsistemima koje će biti prodiskutovane $u$ daljem tekstu.

\section{Odnos sa roditeljima}

Specifičnosti odnosa sa roditeljima pre svega se odnose na izražene razlike u percepciji relacije sa ocem i relacije sa majkom. Dosledno najniži skorovi na svim merenim dimenzijama pripisuju se odnosu sa ocem. Izuzetak čini procena instrumentalne pomoći. Statistički značajno najniži skorovi vezani su za intimnost, prijateljstvo, brigu za oca ali i sigurnost u trajnost veze sa njim. Za razliku od procenjenog odnosa sa ocem, adolescenti iz uzorka procenjuju dosledno kvalitetnijim odnos sa majkom. Procenjen kvalitet relacija viši je u svim elementima pozitivne razmene $u$ odnosu na druge merene odnose, a niži $\mathrm{u}$ elementima negativne razmene $\mathrm{u}$ odnosu na sibling relaciju. Najviši skorovi kada je u pitanju odnos sa majkom vezuju se za subskale koje mere 
instrumentalnu pomoć, ali i druge elemente pozitivne emotivne i socijalne razmene: privrženost, poštovanje i poverenje u trajnost veze.

Percipiran kvalitetan odnos sa majkama je rezultat koji se dosledno ponavlja u većini domaćih istraživanja koja se bave tom tematikom. Adolescenti uglavnom procenjuju da imaju dobre odnose sa roditeljima, posebno dobru komunikaciju sa majkom. Majka je, gotovo bez izuzetka, u istraživanjima procenjena kao izrazito topla i popustljiva u vaspitnom ponašanju (Genc,1988; Genc i Kodžopeljić, 1995; Mihić, 2005; Mihić i sar, 2006; Petrović, 2007). Sa druge strane, slika emocionalno dezangažovane relacije sa ocem karakteristična je za tradicionalnu koncepciju porodične uloge oca, kao zaduženog, pre svega, za materijalno obezbeđivanje porodice. Emotivna razmena i nega pre svega su društvena očekivanja vezana za ulogu majke i dosledno se održavaju bez obzira na zahteve za egalitarnošću koji se promovišu u aktuelnom društvu. Istraživanja koja prate definisanje roditeljskih i porodičnih uloga još uvek u značajno većem procentu beleže izraženost tradicionalne, jasne dihotomije, po kojoj je briga o deci dosledno pripisivana majci. U aktuelnim porodicama, ukoliko se i pripisuje ocu, briga o deci koncipirana je tako da podržava težište očeve aktivnosti van kuće i podrazumeva „razvoženje“, fizičku pomoć, što i jesu interakcije u oblasti instrumentalne pomoći, prepoznate kao karakteristike odnosa sa ocem (Mihić i sar, 2006, Petrović, 2007).

Danas se u svetu sve više povećava broj porodica u kojima roditelji jednako materijalno pridonose porodici, jer broj zaposlenih žena raste velikom brzinom, dok uloga očeva u podizanju dece postaje sve značajnija. Takva očekivanja se promovišu i u Srbiji, i istraživanja ukazuju na značajne pozitivne efekte veće uključenosti oca (Zotović i sar., 2007) Međutim, rezultati ovog istraživanja ukazali su da se preko majke i dalje zadovoljavaju emocionalne, unutrašnje potrebe deteta, a otac znači samo spoljnu, organizacijsku, ekonomsku i društvenu sigurnost, kako za dete, tako i za čitavu porodicu. Majka zapravo kontinuirano nastavlja telesnu i emocionalnu negu deteta, a otac ostaje na položaju spoljnjeg osiguranja za nesmetano realizovanje ekskluzivne uloge majke kao primarnog staratelja.

Rezultati istraživanja ukazuju i na pravilnost formiranja polno ujednačenih saveza unutar porodice. Ispitanice izveštavaju o kvalitetnijem odnosu sa majkom u odnosu na ispitanike, dosledno procenjujući sve merene dimenzije višim, od čega statističku značajnost dosežu prijateljstvo i intimnost. Slično tome, ispitanici procenjuju odnos sa ocem kao kvalitetniji u odnosu na ispitanice, posebno intimnost i dobijanje instrumentalne pomoći od oca. Podatak da mladići izveštavaju o kvalitetnijem odnosu sa ocem, a devojke sa 
majkom dobijen je i u drugim istraživanjima (npr. Petrović, 2006). Ovi rezultati potvrđuju nalaze drugih studija o tome da je interakcija adolescenata češća sa roditeljem istog pola, kao i da se prisan odnos sa roditeljem suprotnog pola u adolescenciji smanjuje (Kapor Stanulović, 2008), što povećava verovatnoću pojave većeg stepena intimnosti u odnosu sa istopolnim roditeljem. Specifičnosti ovako formiranih relacija uočene u ovom istraživanju tiču se, pre svega, temelja na kojima se istopolni savezi formiraju. Naime, dok se između majki i ćerki intenzivira emotivna razmena, intimnost, poveravanje, između očeva i sinova uz izraženiju intimnost, izostaje emotivna, a raste instrumentalna razmena. Ovim se zadržava vrednost da su ženske figure u porodici u većoj meri usmerene na afektivni život, dok se kod muških figura zadržava racionalnost i podrška na neemocionalnom nivou.

\section{Odnos u sibling relaciji}

Kada je u pitanju percepcija kvaliteta odnosa u relaciji sa siblingom, $u$ istraživanju predstavljenom ovim radom, najviši skorovi vezuju se za dimenzije koje mere negativnu interakciju (konflikti i antagonizam), ali $u$ isto vreme i na dimenziji Prijateljstvo. Na ostalim relacijama, razlike u odnosu na procenu odnosa sa roditeljima nisu statistički značajne. Rezultati koji govore o odnosu sa siblingom su potpuno očekivani - adolescenti izveštavaju o visokom stepenu bliskosti, recipročnosti odnosa, ali i negativne razmene. Ovakav obrazac potvrđuje se u većem broju istraživanja koja, takođe, utvrđuju izraženost companionshipa u relaciji sa siblingom (Cole, Kerns, 2001), značajne razlike između percepcije odnosa sa roditeljima i odnosa u sibling relaciji (Scharf i sar, 2005) i ističe postojanje i pozitivnih i negativnih dimenzija sibling odnosa (Furman \& Buhrmester, 1985; Scharf i sar, 2005). Zapravo, istovremeno postojanje bliskosti i konflikata govori nam da oni ne predstavljaju suprotnosti jedne dimenzije, već da se radi o zasebnim dimenzijama kvaliteta odnosa, gde obe mogu biti visoko procenjene kada je interakcija među članovima intenzivna. S druge strane, sibling subsistem spada u tzv. "horizontalne" porodične odnose (za razliku od odnosa sa roditeljima), gde je dozvoljeno otvorenije ispoljavanje negativnih emocija, a i institucionalna priroda porodice garantuje opstanak sibling odnosa i pored čestih neslaganja i konflikata. Neki istraživači u tom smislu govore o ambivalentnim osećanjima dece prema drugom članu sibling dijade, ali se uglavnom naglašava ravnopravnost u ovom obliku interakcije (Furman, Buhrmster, 1992). Radova koji bi ukazivali na kulturne specifičnosti odnosa u sibling relaciji gotovo da i nema. U tradicionalnim srpskim porodicama, stariji siblinzi najčešće dobijaju status „pomoćnog staratelja" čime se njihova pozicija u sistemu izmešta sa horizontalnog na vertikalni 
nivo. Ovakva pozicija rizična je za razvoj trianguliranih odnosa, reverzije uloga i sličnih karakteristika odnosa koji se mogu negativno odraziti na kvalitet i funkcionalnost pojedinih porodičnih relacija, ali i porodice u celini. Potrebna su dodatna istraživanja kako bi se jasnije opisale karakteristike odnosa u sibling relaciji.

\section{Zaključak}

U istraživanjima porodičnih odnosa u Srbiji danas, uglavnom se ističe izražena emocionalnost $\mathrm{i}$ bliskost $\mathrm{u}$ relacijama među članovima porodice, uz visoku vrednost samih porodičnih odnosa koji su viđeni kao sigurna baza u nošenju sa traumama i stresom koje je većina porodica u Srbiji imala (Gačić i Marković, 2004; Gajić-Draganić, Stamenković-Rudić, 2004, Zotović i sar, 2008). Istraživanje predstavljeno ovim radom doprinelo je razmevanju karakteristika pojedinačnih odnosa unutar porodice. Dok relaciju sa majkom karakteriše izraženo blizak, gotovo nekritičan odnos, uloga oca se, sa snažne moralne figure, koja nameće i sprovodi pravila (što je bila pozicija oca u tradicionalnim sistemima) u ovom istraživanju svela na „bleđu“ kopiju relacija sa majkom. Sa jedne strane to upućuje na ujednačenu procenu roditeljskih figura, koja se uočava u rezultatima istraživanja kojima se prate sličnost opažanja vaspitnih stilova očeva i majki (Mihić i sar, 2006). Takođe, ovaj rezultat otvara pitanje gubljenja tradicionalnih specifičnosti uloga roditelja uz nedovoljno uspostavljene redefinisane uloge kojima se otac više uključuje $u$ porodični život što je uočeno i u ranijim istraživanjima. Naime, dok istraživanja ukazuju na dominantno egalitarna uverenja o ulogama u porodici kod majki, kod očeva su još uvek evidentna, ne samo uverenja (Mihić, 2007), već se i tradicionalnost porodica bazira na njihovoj izraženoj neuključenosti u domene porodičnog života koji su tradicionalno bili uloga majke - kakva je nega deteta, briga o kući i slično (Mihić i sar, 2006; Petrović, 2007). Ipak, tamo gde je otac uključen u ove aspekte porodičnog života, porodični odnosi se procenjuju kao funkcionalniji (Zotović, i sar 2007). Relacija sa siblingom očekivano pokazuje više simetričnosti, uz izražen nivo i pozitivne i negativne razmene.

Pitanje koje se postavlja na osnovu ovih rezultata se pre svega odnosi na mogućnost razvojne individuacije i separacije u izraženo bliskim relacijama, kakva je uočena relacija sa majkom. Odgovor na ovo pitanje mogao bi da doprinese i razumevanju transgeneracijskog održavanja ili promena obrazaca porodičnih relacija i uloga. 


\section{Reference:}

Bronfebrener J. (1988). Ekologija ljudskog razvoja. Zavod za udžbenike i nastavna sredstva, Beograd.

Bryant B(1985). The neigrhborhood walk: a study of sources of support in middle childhood from the child's perspective. Monographs of the society for research in child development, 50 (3).

Buhl H. (2008). Significance of individuation in adult child parent relationships. Journal of Family Issues, 29 (2) , 262-281.

Buhrmester D, Furman W. (1987). The development of companionship and intimacy. Child Development, 58, 1101-1103 .

Buhrmester D. (1990). Intimacy of friendship, interpersonal competence and adjustment during preadolescence and adolescence. Child Development, 61 (4), 1101-1111.

Buhrmester D., Furman W (1990). Perception of sibling relations durin middle childhood and adolescence. Child Development, 61 (5), 1387 1398.

Cicirelli V. (1994). Sibling relationship in cross- cultural perspective. Journal of Marriage and the Family, 56, 7-20.

Cole A., Kerns K. (2001). Perception of sibling qualities and activities in early adolescence. The Journal of Early Adolescence, 21 (2), 204-227.

Collins W., Haydon K., Hesemeyer P. (2007). Relating relationships: development, expansions and interrelations in relationship networks. International Journal of Behavioral Development, 31 (6), 581-584.

Collins W.A., Laursen B.(2004).Changig relationships, changig youth: interpersonal context of adolescent development. The Journal of Early Adolescence, 24 (1), 55-62.

Furman D., Buhrmester W. (1992). Age and sex differences in perception of networks of personal relationships. Child Development, 63, 203-115.

Furman W., Buhrmester D. (1985). Children's perception of sibling relationships. Child Development, 56(2), 448-461.

Gačić B, Trbić V., Marković M (2004). Funkcionisanje porodice u društvenom kontekstu hronične krize u Jugoslaviji. U: Veselinović J (ed). Izazovi porodica, izazovi porodičnih terapeuta u vremenu tranzicije. Beograd, Centar za porodicu. 
Gajić-Draganić S., Stamenković-Rudić B. (2004). Tranzicija- izazov braku. U: Veselinović J. (ed). Izazovi porodica, izazovi porodičnih terapeuta u vremenu tranzicije. Beograd, Centar za porodicu.

Gavin L., Furman W. (1996). Adolescent girl's relationships with mothers and best friends. Child Development, 67 (2), 375-386.

Genc, L. (1988). Dimenzije vaspitanja i razvoj ličnosti: teorije i istraživanja. Psihologija, 5, 121-132.

Genc, L., i Kodžopeljić, J. (1995). Porodično vaspitanje i dimenzije ličnosti. U: Đ. Đurić, (ur.). Ličnost u višekulturnom društvu, 2. Novi Sad: Filozofski fakultet, Odsek za psihologiju.

Georgias J., Mylonas K., Bafiti T., Poortinga Y., Christakopoulou S., Kagitcibasi C., Kwak K., Ataca B., Berry J., Orung S., Sunar D., Charalambous N., Goodwin R., Wang W., Angleitner A., Stepanikova I., Pick S., Givaudan M., Zuravliova I., Konantambigi R., Gelfand M., Marinova V., Mc Bride-Chang C., Kodic J. (2001).Functional relationships in nuclear and extended family: a 16 culture study. International Journal of Psychology, 36 (5), 289-300.

Kapor-Stanulović N (2008). Na putu ka odraslosti. Zavod za udžbenike i nastavna sredstva. Beograd.

Mc Goldric M (1998). Re-visioning family therapy: race, culture and gender in clinical practice. New York, London, Guilford Press.

Mc Goldric M., Giordano J. (1996). Overview: Ethnicity and family therapy. In: Mc Godldric M., Giordano J., Pearce J.K (eds). Ethnicity and Family Therapy. New York, London, Guilford Press.

Mihić I. (2007). Roditeljstvo u porodicama sa adolescentom: faktori kvaliteta. Beograd, Zadužbina Andrejević

Mihić I., Zotović M., Petrović J. (2006). Sociodemografske karakteristike porodice, podela posla u kući i vaspitni stilovi roditelja u porodicama na teoritoriji Vojvodine. Pedagoška stvarnost, 1-2, 118-134.

Mihić, I. (2005). Uloga vaspitnog stila roditelja u proceni porodice. U: Franceško, M. i M. Zotović (Ur.). Ličnost u višekulturnom društvu: Psihosocijalni aspekti društvene tranzicije u Srbiji. Novi Sad, Odsek za psihologiju Filozofskog fakulteta u Novom Sadu, 238-254.

Petrović J. (2006). Percepcija kvaliteta socijalnih odnosa u adolescenciji. Teme, 2, 291-306. 
Petrović J. (2007). Odnosi u porodicama u Vojvodini: podela uloga,vaspitno ponašanje roditelja i porodična klima. U: Zotović M. (ur). Porodice $u$ Vojvodini: karakteristike i funkcionalnost. Novi Sad, Filozofski fakultet.

Scharf M., Shulman S., Avigad-Spitz L. (2005). Sibling relationships in emerging adulthood and adolescence. Journal of Adolescent Research, 20 (1), 64-90.

Somerwill R.(1965).The family in Yugoslavia. Journal of Marriage and the Family, 27 (3), 350-362.

Tomanović S. (2004).Roditeljstvo u transformaciji: kapitali, problemi, strategije. U: Milić A (ed). Društvena transformacija $i$ strategije društvenih grupa: svakodnevica Srbije na početku trećeg milenijuma. Beograd, Institut za sociološka istraživanja Filozofskog fakulteta.

Urberg, K.A., Degirmencioglu S.M., Tolson J.M., Halliday-Scher K. (1995). The structure of adolescent peer networks. Developmental Psychology, 31, 540-547.

Van Horn K.R., Marques J.C. (2000). Interpersonal relationships in Brazilian adolescents. International Journal of Behavioral Development, 24 (2), 199203.

Wissink, I., Dekovic M., Meijer A. (2006). Parenting behavior, quality of parent-adolescent relationship and adolescent functioning in four ethnic groups. The Journal of Early Adolescence, 26 (2), 133-159.

Zotović M., Telečki T., Mihić I. (2008). Relacije karakteristika porodice i prevladavanja stresa kod adolescenata. Primenjena psihologija, 1 (3-4), 145-160.

Zotović, M., Mihić, I., Petrović, J. (2007). Socio-demografske i psihološke karakteristike tradicionalnih i egalitarnih porodica sa teritorije Vojvodine. U: M. Biro, S. Smederevac (eds). Psihologija i društvo. Novi Sad: Filozofski fakultet, 151-162. 
Apstract

\section{THE QUALITY OF FAMILY RELATIONS AS PERCIEVED BY SERBIAN ADOLESCENTS}

Ivana Mihić and Jelica Petrović

The research presented in this paper aims to describe different intra-familial relations as perceived by adolescents. Mother-child, father-child and sibling dyadic relations were evaluated by the sample of 780 youths (average age 19).

The quality of family relations was assessed by Network of Relationships Inventory (NRI, Furman, Buhrmaster, 1985). The NRI version used in this research allows assessement of 9 dimensions of a dyadic relationships: Companionship, Instrumental Aid, Intimacy, Reliable Alliance, Admiration, Nurturance and Affection- measuring positive dyadic interaction and Conflic and Antagonism as measures of negative dyadic interaction.

Results indicate significant differences in perception of mother-child and father-child relations that could be explained as effects of traditional parenting roles. Sibling dyadic interaction is significantly more simetric comparing to parent-child relations.

Results are discussed in the context of ecological models predicting culturalspecific characteristics of relationships, revealing impacts of dominating cultural values of family and intra-familial relations in Serbia.

Key words: adolescence, family relations

Primljeno: 1.10.2009; prihvaćeno za štampu: 5.12.2009. 